\title{
A Natural Product Telomerase Activator As Part of a Health Maintenance Program
}

\author{
Calvin B. Harley, ${ }^{1,6}$ Weimin Liu, ${ }^{2}$ Maria Blasco, ${ }^{3}$ Elsa Vera, ${ }^{3}$ William H. Andrews, ${ }^{4}$ \\ Laura A. Briggs, ${ }^{4}$ and Joseph M. Raffaele ${ }^{5}$
}

\begin{abstract}
Most human cells lack sufficient telomerase to maintain telomeres, hence these genetic elements shorten with time and stress, contributing to aging and disease. In January, 2007, a commercial health maintenance program, PattonProtocol-1, was launched that included a natural product-derived telomerase activator (TA- $65^{\circledR}, 10-50 \mathrm{mg}$ daily), a comprehensive dietary supplement pack, and physician counseling/laboratory tests at baseline and every 3-6 months thereafter. We report here analysis of the first year of data focusing on the immune system. Low nanomolar levels of TA- $65^{\circledR}$ moderately activated telomerase in human keratinocytes, fibroblasts, and immune cells in culture; similar plasma levels of TA- $65^{\circledR}$ were achieved in pilot human pharmacokinetic studies with single 10- to 50-mg doses. The most striking in vivo effects were declines in the percent senescent cytotoxic $\left(\mathrm{CD}^{+} / \mathrm{CD} 28^{-}\right) \mathrm{T}$ cells $(1.5,4.4,8.6$, and $7.5 \%$ at 3, 6, 9, and 12 months, respectively; $p=$ not significant [N.S.], $0.018,0.0024,0.0062)$ and natural killer cells at 6 and 12 months ( $p=0.028$ and 0.00013 , respectively). Most of these decreases were seen in cytomegalovirus (CMV) seropositive subjects. In a subset of subjects, the distribution of telomere lengths in leukocytes at baseline and 12 months was measured. Although mean telomere length did not increase, there was a significant reduction in the percent short $(<4 \mathrm{kbp})$ telomeres $(p=0.037)$. No adverse events were attributed to PattonProtocol-1. We conclude that the protocol lengthens critically short telomeres and remodels the relative proportions of circulating leukocytes of $\mathrm{CMV}^{+}$subjects toward the more "youthful" profile of $\mathrm{CMV}^{-}$subjects. Controlled randomized trials are planned to assess TA- $65^{\circledR}$-specific effects in humans.
\end{abstract}

\section{Introduction}

$\mathbf{P}$ EOPLE TAKE DIETARY SUPPLEMENTS with the intent to preserve mental, physical, and emotional health and vigor into old age. Although drugs and surgical procedures that target diseases of the elderly will hopefully arrest or partially reverse tissue damage caused by aging and chronic stress, measures to maintain health are arguably a better approach to lengthening our healthy life span. Most dietary supplement programs include combinations of vitamins, antioxidants, and other constituents, some of which have been shown to have significant health benefits in controlled clinical studies, whereas others may show adverse effects, ${ }^{1-6}$ underscoring the need to assess functional effects of combination products. This paper presents initial data from an ongoing observational study of a novel dietary supplement program, PattonProtocol-1, which includes a natural product-derived telomerase activator targeting a fundamental aspect of cellular aging.

Telomerase is an enzyme that synthesizes the specific DNA sequence at telomeres, i.e., the terminal DNA at the ends of all chromosomes. ${ }^{7,8}$ Telomeres are essential genetic elements responsible for protecting chromosome ends from being recognized as "broken DNA." Because telomeric DNA cannot be fully replicated by conventional DNA polymerases, and because telomeres undergo degradative processing and are a "hotspot" for oxidative damage," telomeres will gradually shorten with time and cell division unless there is sufficient telomerase activity to maintain telomere length.

\footnotetext{
${ }^{1}$ Geron Corporation, Menlo Park, California.

${ }^{2}$ TA Sciences, New York, New York.

${ }^{3}$ Spanish National Cancer Center, Madrid, Spain.

${ }^{4}$ Sierra Sciences, Reno, Nevada.

${ }^{5}$ PhysioAge Systems, New York, New York.

${ }^{6}$ Present address: Telome Health Inc., Menlo Park, California.
} 
Telomerase is activated in fetal development, thus protecting telomeres from significant loss during this period of dramatic cell expansion. ${ }^{10,11}$ However, telomerase is repressed before birth in most somatic tissue, and, as a consequence, birth marks the beginning of telomere erosion in most tissues throughout life. Tissues with continual cell turnover or periods of rapid proliferation are "telomerase competent" in that they upregulate telomerase during early phases of progenitor expansion. ${ }^{12,13}$ All adult somatic stem cells appear to be capable of activating telomerase during tissue regeneration. However, these periods of activation are insufficient to prevent telomere loss, and this is compounded by a decreased ability to activate telomerase during aging and stress. ${ }^{14-16}$ In addition, stress can accelerate telomere loss by increasing cell turnover and the amount of telomeric DNA lost per cell division. ${ }^{17,18}$

In cross-sectional studies, humans lose telomeric DNA at a very modest rate of about $15-60 \mathrm{bp}$ per year, likely reflecting the small numbers of stem cells that are actively dividing in proliferative tissues compared to the total stem cell reserve, and the quiescent state of cells in other tissues. Telomere shortening has been investigated in human cells in culture, in human genetic diseases with mutated telomerase, and in animal models of telomerase deficiency. ${ }^{13,19-26}$ These studies point to a causal relationship between telomere loss, cell aging, reduced tissue regeneration, and loss of tissue structure and function. In support of this causal relationship, epidemiological studies show that short telomeres in humans are a risk factor for atherosclerosis, hypertension, cardiovascular disease, Alzheimer disease, infections, diabetes, fibrosis, metabolic syndrome, cancer, and overall mortality. ${ }^{18,24,25,27-30}$

Chronic viral infections such as cytomegalovirus (CMV) and human immunodeficiency virus (HIV) accelerate telomere loss and premature aging of the immune system, especially the virus-specific cytotoxic $\mathrm{T}$ cells ${ }^{31-36}$ responsible for killing infected cells. In addition to telomere loss, these cells often lack expression of the co-stimulatory receptor CD28 and have reduced proliferative capacity, reduced ability to secrete antiviral cytokines and chemokines, increased resistance to apoptosis, and compromised ability to lyse infected cells. About $50 \%$ of the U.S. population is infected with CMV as judged by circulating CMV-specific antibodies, but after an initial 30\% seropositivity rate by age $\approx 10$, there is $\approx 1 \%$ annual seroconversion rate throughout life leading to $\approx 90 \%$ seropositivity by the ninth decade. This linear increase has made it difficult to distinguish the effects of pure immunosenescence from those that can be attributed to this extremely common virus. ${ }^{37,38}$

Here we report initial findings from a dietary supplement program which includes TA- $65^{\circledR}$, a purified smallmolecule telomerase activator derived from an extract of a plant commonly used in traditional Chinese medicine. Telomerase activation and functional studies on a related molecule (TAT2) from the same plant have been previously reported for human skin keratinocytes and immune cells in culture. ${ }^{36}$ Effects of TAT2 in tissue culture studies with $\mathrm{CD}^{+} \mathrm{T}$ cells from HIV/acquired immunodeficiency syndrome (AIDS) subjects included increased replicative capacity, improved cytokine and chemokine responses to antigens, and increased killing of autologous HIV-infected $\mathrm{CD} 4^{+}$cells.

\section{Methods}

\section{PattonProtocol-1}

PattonProtocol-1 was launched in January, 2007, by TA Sciences (New York) as a commercial age-management product composed of a natural product-derived telomerase activator (TA-65 ${ }^{\circledR}$, described below), a dietary supplement pack (online material S1), laboratory testing (Table 1), and physician counseling. All subjects signed a comprehensive Customer Acknowledgement Form. Baseline assays (Tables 1 and 2) indicated that most individuals were within the normal ranges for the majority of tests. In a small number of cases described in the Results section, the consulting physician prescribed medications for subjects based upon clinical tests. There was no qualitative change in the overall conclusions whether these subjects were included or censored from the analysis. We report results for all evaluable subjects who completed 12 months of the protocol by June, 2009. The number of subjects at 3, 6, 9, and 12 months for most tests was 43, 59, 27, and 37, respectively. The age and gender frequencies of the subset at each time point were similar to those of the total baseline population $(n=114 ; 63 \pm 12$ years, $72 \%$ male).

\section{$T A-65^{\circledR}$}

TA- $65^{\circledR}$, exclusively licensed to TA Sciences from Geron Corporation, is a $>95 \%$ pure single chemical entity isolated from a proprietary extract of the dried root of Astragalus membranaceus and formulated into 5- to 10-mg capsules with inert excipients. Starting doses of $5-10 \mathrm{mg} /$ day were considered safe on the basis of historical usage of extracts. Some subjects increased their dosage after several months on the product to $25-50 \mathrm{mg} /$ day. Cumulative dose consumed during the year was recorded for each subject and used for preliminary dose-response analysis.

\section{Clinical laboratory assays}

At baseline and each time, point blood samples were drawn and shipped the same day at ambient temperature to analytical laboratories. Assays for standard blood counts, blood chemistry, specialized immune subsets, CMV antibody titer, and inflammation markers were conducted at Quest Diagnostics or Bio-Reference Laboratory. Specialized immune subset analyses were conducted at UCLA Clinical Laboratories and Pathology Services.

\section{Telomerase activity assay in cultured human keratinocytes and fibroblasts}

Telomerase activity was measured in human neonatal keratinocytes (Cascade Biologics, Portland, OR) and in MRC5 fetal human fibroblasts (ATCC\# CCL-171) pre-and posttreatment in culture with TA- $65^{\circledR}$ using the telomere repeat amplification protocol (TRAP) assay, essentially as described elsewhere. ${ }^{39}$ In brief, telomerase activity was measured in actively growing cells incubated for $24-48 \mathrm{~h}$ with TA- $65^{\circledR}$ in the vehicle (dimethylsulfoxide [DMSO] at $1 \%$ $\mathrm{vol} / \mathrm{vol}$ [keratinocyte culture] or $0.5 \%$ [fibroblasts]) versus vehicle alone. Measurements were typically made at 5-10 population doublings (PD) (keratinocytes) or 30-40 PD (fibroblasts). Telomerase reaction products were resolved by 


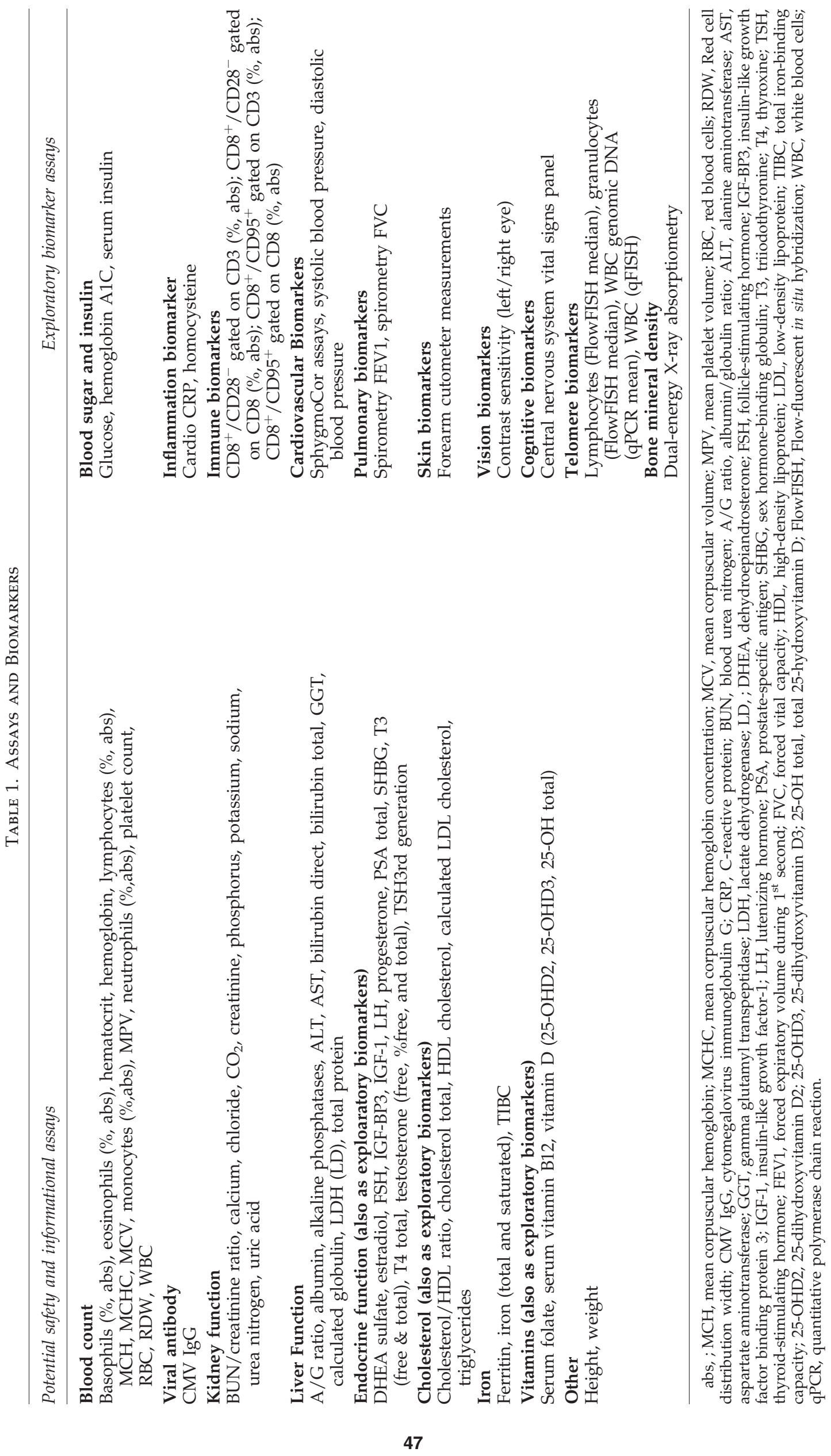




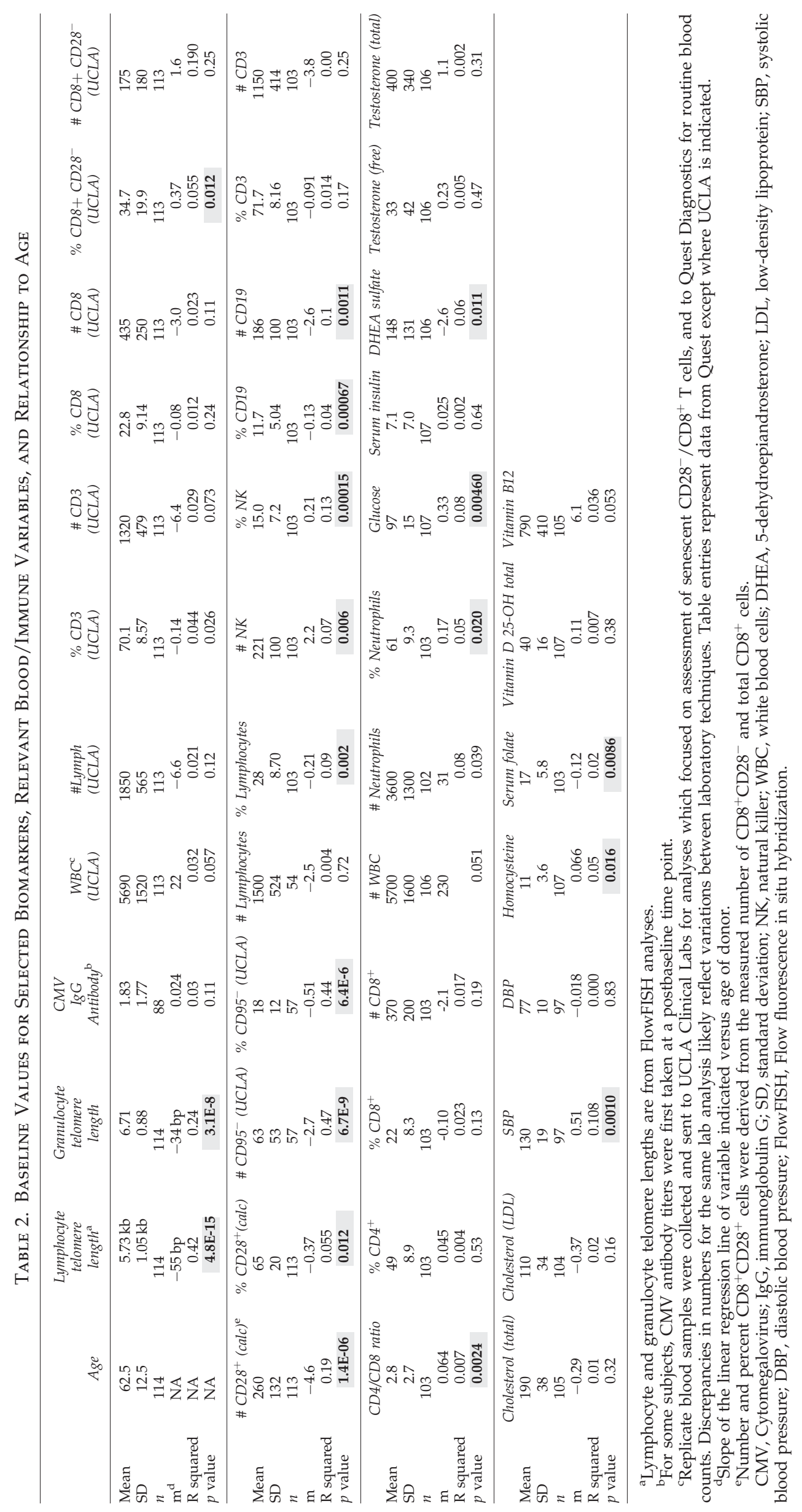


electrophoresis on nondenaturing polyacrylamide gels and quantified by exposure to Phosphor Screens and imaging on PhosphoImager SL (Molecular Dynamics).

\section{Telomere length assays}

Median telomere length in peripheral lymphocytes and granulocytes was determined by FlowFISH at Repeat Diagnostics (Vancouver, Canada) essentially as described elsewhere. ${ }^{40}$ Mean telomere length by $\mathrm{qPCR}^{41}$ was performed in the laboratory of Dr. Richard Cawthon (University of Utah, Salt Lake City, UT). High-throughput quantitative fluorescence in situ hybridization (HT qFISH) ${ }^{42}$ was performed at $\mathrm{CNIO}$, Madrid, for inter- and intranuclear telomere length distributions.

\section{Statistics}

Data from this study were collected primarily as a hypothesis-generating exercise because subjects were not participating in a controlled prospective study, and statistical analyses were not formally defined a priori. Baseline data were analyzed for cross-sectional age effects. Student $t$-tests were used for comparison of means and the F-distribution for significance of linear regression against subject age. Except where indicated, two-tailed paired $t$-tests were conducted at each time point for comparisons to the baseline values. For percentage of short telomeres analyzed by HT qFISH, individual differences between baseline and postproduct data were analyzed by chi-squared analysis.

\section{Results}

\section{Mechanism of action}

TA- $65^{\circledR}$ activates telomerase in human neonatal keratinocytes and fetal fibroblasts in culture. TA- $65^{\circledR}$ upregulates telomerase activity in low- and mid-passage human neonatal keratinocytes two- to three-fold in a dose-responsive manner (Fig. 1A). In these studies, activation was two- to three-fold at the lowest concentrations tested (30-100 nM), and activation was not as great at higher concentrations. This pattern is similar to that seen for TAT2, a related molecule tested in human immune cells. ${ }^{36}$ The ability of TA- $65^{\circledR}$ to upregulate telomerase activity was also tested in human fetal fibroblasts (MRC5) over a broad concentration range (Fig. 1B). Untreated and vehicle (DMSO)-treated MRC5 cultures showed extremely weak telomerase activity; there was essentially no telomerase extension products with a size greater than that of $\mathrm{T} 1$, the minimum size needed to detect a product in the TRAP assay. Results from three independent experiments indicated that TA- $65^{\circledR}$ at concentrations as low as $1 \mathrm{nM}$ induced processive telomerase activity in MRC5 cells. Telomerase activation by $\mathrm{TA}-65^{\circledR}$ in the $1-30 \mathrm{nM}$ range in multiple cell types is important, because plasma levels of TA$65^{\circledR}$ are typically in the $1-20 \mathrm{nM}$ range $4-8 \mathrm{~h}$ postoral ingestion of $5-100 \mathrm{mg}$ TA- $65^{\circledR}$ (unpublished data).

\section{Baseline observations}

The relationships between age and various biomarkers including telomere length have been reported in a number of cross-sectional studies. Table 2 shows mean values, standard deviations, count, slope, and $\mathrm{R}^{2}$ from linear regression on

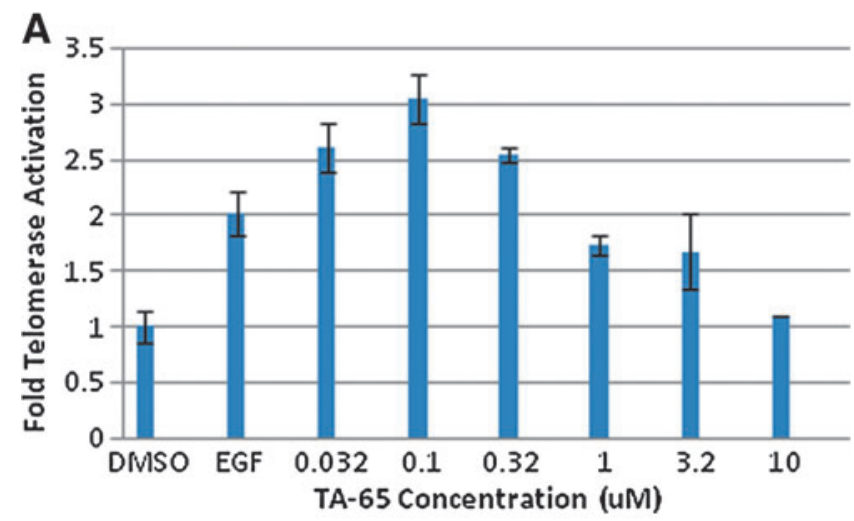

B

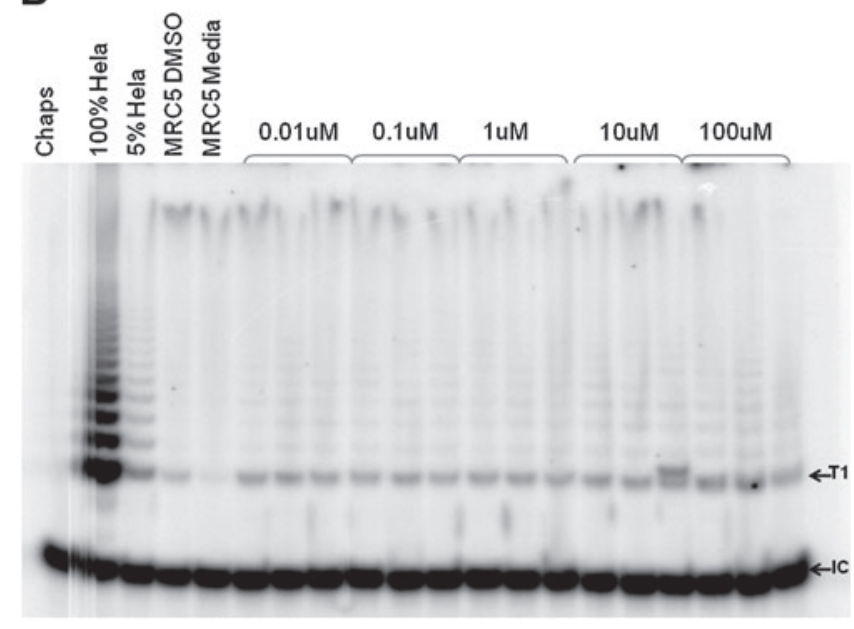

FIG. 1. Telomerase activation by TA- $65^{\circledR}$ in neonatal foreskin keratinocytes and fetal lung MRC-5 fibroblasts. (A) Keratinocytes in triplicate wells were exposed for $48-72 \mathrm{~h}$ in different experiments to the dimethylsulfoxide (DMSO) vehicle control, epidermal growth factor (EGF) (positive control, typically $10 \mathrm{ng} / \mathrm{mL}$ ), or TA- $65^{\circledR}$ at indicated concentrations, and products were analyzed as described in Methods. Results from analysis of telomere repeat amplification protocol (TRAP) ladders resolved by gel electrophoresis and quantified by ImageQuant on a PhosphoImager are shown for a typical experiment. (B) MRC-5 cells were exposed to $\mathrm{TA}-65^{\circledR}$ at concentrations shown for $48 \mathrm{~h}$. Each replicate represents an independent lysate (a replicate culture dish within one experiment). "Chaps" represents the lysis buffer control (no cell extract). HeLa cells are used as positive control cells as described in Methods. T1 is the first telomerase extension product capable of amplification by PCR. IC is the internal control PCR product. Shown is a representative gel from three independent experiments.

subject age, and the statistical significance of the slope for the baseline tests investigated in this report. As expected, this population showed a highly significant decline as a function of client age in both lymphocyte and granulocyte telomere length by FlowFISH analysis, and the slopes of the decline (55 and $34 \mathrm{bp} /$ year; $p=10^{-15}$ and $10^{-8}$, respectively) are comparable to those reported previously. ${ }^{43-45}$ Age-dependent increases are seen in the percent senescent $\left(\mathrm{CD} 8^{+} \mathrm{CD} 28^{-}\right)$ cytotoxic $\mathrm{T}$ cells, percent natural killer (NK) cells, and percent and absolute number of neutrophils. Significant 
A Baseline Lymphocyte Telomere Length
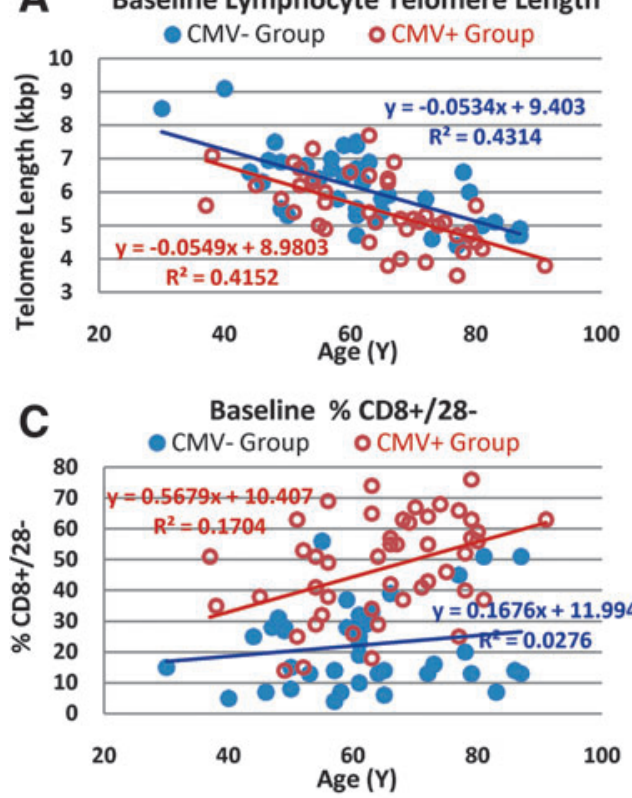

E Baseline \% CD8+

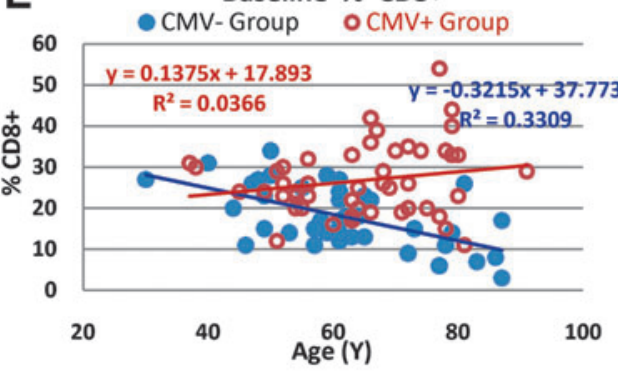

G Baseline \% CD95-/CD8+
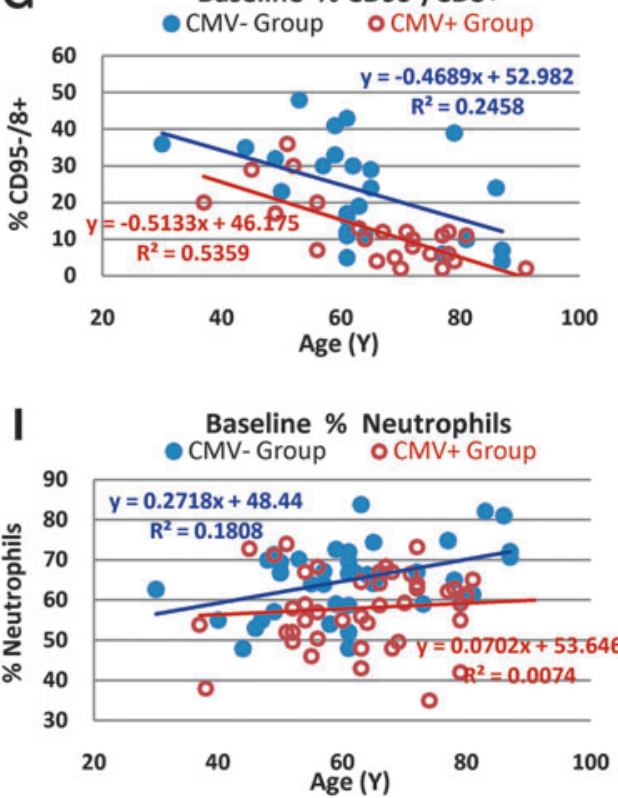

B Baseline Granulocyte Telomere Length
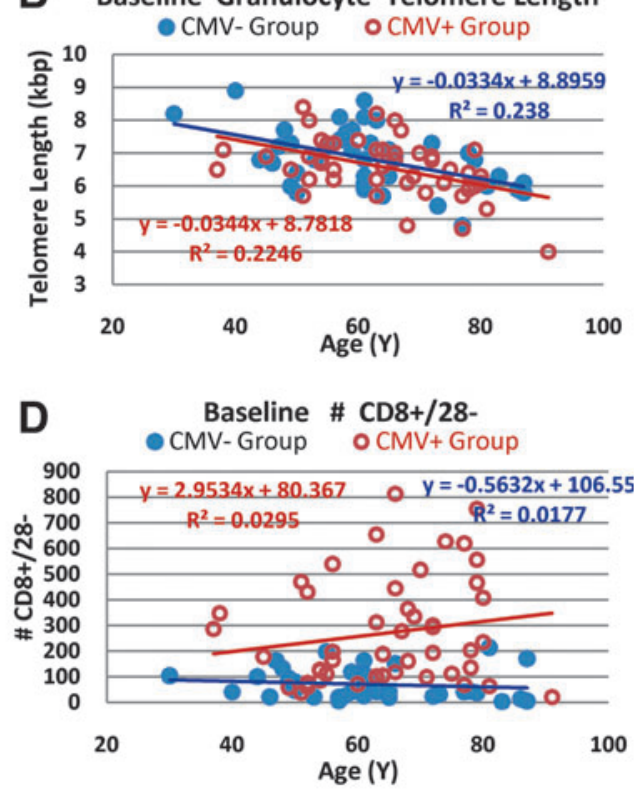

F Baseline \# CD8+

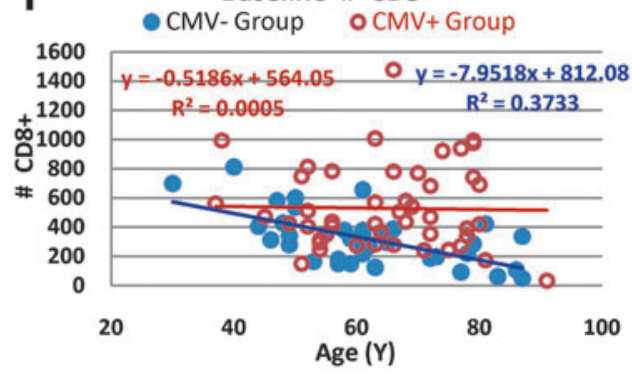

H Baseline \# CD95-/CD8+

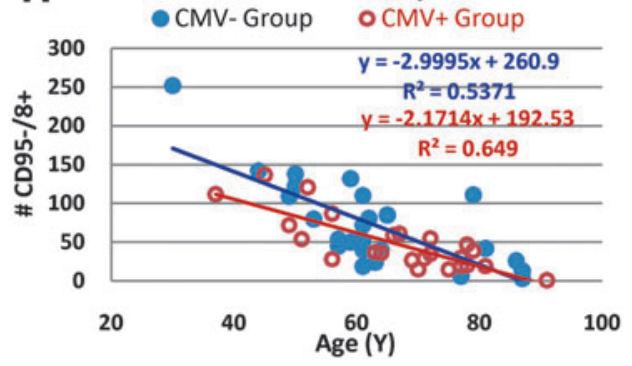

J Baseline \# Neutrophils

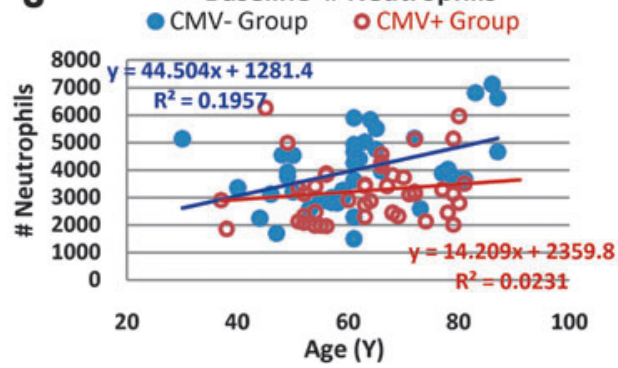

FIG. 2. Baseline telomere length and immune subset data as a function of subject age segregated by cytomegalovirus (CMV) status. Overall baseline data without segregation by CMV status is provided in Table 2. Correlations with age for lymphocyte and granulocute telomere length $(\mathbf{A}, \mathbf{B})$ and immune subsets $(\mathbf{C}-\mathbf{J})$ at baseline were determined by linear regression in the $\mathrm{CMV}^{+}$and $\mathrm{CMV}^{-}$subjects. Telomere length and immune parameters were analyzed by flow cytometry as described in Methods. 
Table 3. Baseline Immune Subsets By Cytomegalovirus status

\begin{tabular}{|c|c|c|c|c|}
\hline Immune parameter & & $C M V^{+}$ & $C M V^{-}$ & $\mathrm{t}$-test \\
\hline White blood cells & \# & 5464 & 6037 & 0.104 \\
\hline Neutrophils & $\begin{array}{l}\% \\
\#\end{array}$ & $\begin{array}{r}58 \\
3259\end{array}$ & $\begin{array}{r}65 \\
4025\end{array}$ & $\begin{array}{l}\mathbf{0 . 0 0 3} \\
0.022\end{array}$ \\
\hline Monocytes & $\begin{array}{l}\% \\
\#\end{array}$ & $\begin{aligned} & 7.8 \\
& 429\end{aligned}$ & $\begin{aligned} 7.4 \\
449\end{aligned}$ & $\begin{array}{l}0.453 \\
0.557\end{array}$ \\
\hline Lymphocytes & $\begin{array}{l}\% \\
\#\end{array}$ & $\begin{array}{c}35.3 \\
1927\end{array}$ & $\begin{array}{c}29.9 \\
1830\end{array}$ & $\begin{array}{l}0.025 \\
0.292\end{array}$ \\
\hline $\begin{array}{l}\mathrm{CD}^{+} 9^{+} \\
\text {B cell }\end{array}$ & $\begin{array}{l}\% \\
\#\end{array}$ & $\begin{array}{l}\mathbf{1 0 . 8} \\
192\end{array}$ & $\begin{array}{l}12.9 \\
189\end{array}$ & $\begin{array}{l}\mathbf{0 . 0 0 7} \\
0.334\end{array}$ \\
\hline $\begin{array}{l}\mathrm{CD} 56^{+}, \mathrm{CD}_{16}{ }^{+}, \mathrm{CD}^{-} \\
\text {Natural killer cell }\end{array}$ & $\begin{array}{l}\% \\
\#\end{array}$ & $\begin{array}{l}14.1 \\
220\end{array}$ & $\begin{array}{r}16 \\
221\end{array}$ & $\begin{array}{l}0.433 \\
0.953\end{array}$ \\
\hline $\begin{array}{l}\mathrm{CD}^{+} \\
\mathrm{T} \text { cell }\end{array}$ & $\begin{array}{l}\% \\
\#\end{array}$ & $\begin{array}{r}72 \\
1416\end{array}$ & $\begin{array}{r}68 \\
1202\end{array}$ & $\begin{array}{l}\mathbf{0 . 0 0 1} \\
0.03\end{array}$ \\
\hline $\mathrm{CD}^{+}{ }^{+}, \mathrm{CD}^{+}{ }^{+}$ & $\%$ & 47.8 & 49.9 & 0.336 \\
\hline Helper T & \# & 814 & 734 & 0.332 \\
\hline $\mathrm{CD}^{+}{ }^{+}, \mathrm{CD}^{+}$ & $\%$ & 27 & 18 & $<0.0001$ \\
\hline $\begin{array}{l}\text { Cytotoxic } \mathrm{T} \\
\text { CD4/CD8 ratio }\end{array}$ & $\#$ & $\begin{array}{l}530 \\
2.12\end{array}$ & $\begin{array}{l}322 \\
3.88\end{array}$ & $\begin{array}{c}<0.0001 \\
0.008\end{array}$ \\
\hline $\begin{array}{l}\mathrm{CD}^{+}, \mathrm{CD}^{2} 8^{+} \\
\text {Normal CD } 8\end{array}$ & $\begin{array}{l}\% \\
\#\end{array}$ & $\begin{array}{r}53 \\
260\end{array}$ & $\begin{array}{r}78 \\
250\end{array}$ & $\begin{array}{l}\mathbf{0 . 0 0 0 1} \\
0.976\end{array}$ \\
\hline $\begin{array}{l}\mathrm{CD}^{+}{ }^{+}, \mathrm{CD} 28^{-} \\
\text {Senescent CD8 }\end{array}$ & $\begin{array}{l}\% \\
\#\end{array}$ & $\begin{array}{l}47.2 \\
272\end{array}$ & $\begin{array}{l}22.3 \\
72\end{array}$ & $\begin{array}{l}<0.0001 \\
<0.0001\end{array}$ \\
\hline $\begin{array}{l}\mathrm{CD}^{-} 5^{-}, \mathrm{CD} 8^{+} \\
\text {Naïve CD8 }\end{array}$ & $\begin{array}{l}\% \\
\#\end{array}$ & $\begin{array}{l}\mathbf{1 2 . 0 0 0} \\
48.000\end{array}$ & $\begin{array}{l}23.000 \\
72.000\end{array}$ & $\begin{array}{l}\mathbf{0 . 0 0 0 5} \\
0.07\end{array}$ \\
\hline
\end{tabular}

$p$ values less than 0.002 are highlighted.

age-dependent decreases are seen in naïve $\left(\mathrm{CD} 8^{+} \mathrm{CD} 95^{-}\right)$ cytotoxic T cells, B cells, and lymphocytes.

Because CMV infection can have a significant impact on immune markers, ${ }^{37,46}$ we analyzed the age-dependency of baseline immune subsets by CMV status (Fig. 2 and Table 3). Lymphocyte, but not granulocyte, telomere length was longer in $\mathrm{CMV}^{-}$subjects than that in $\mathrm{CMV}^{+}$subjects, suggesting that CMV infection drives increased turnover (and hence telomere shortening) in lymphocytes, but has relatively little effect on hematopoietic stem cells. Telomere length in granulocytes is considered a surrogate of telomere length in hematopoietic stem cells due to their short transit time to peripheral blood, and short half-life in circulation. ${ }^{42}$ The ages of the $\mathrm{CMV}^{+}$and $\mathrm{CMV}^{-}$subjects (65 \pm 12 and $62 \pm 13$, respectively) were not significantly different, but the mean lymphocyte telomere length in $\mathrm{CMV}^{+}$individuals was $680 \mathrm{bp}$ less than that observed in the $\mathrm{CMV}^{-}$group $(p=0.003)$, suggesting an acceleration of aging by about 10 years in the $\mathrm{CMV}^{+}$group based on $-55 b p$ per year for lymphocytes.

As expected, baseline numbers and the rate of increase in senescent cytotoxic $\mathrm{T}$ cells $\left(\mathrm{CD}^{+} / \mathrm{CD} 28^{-}\right)$in percent and absolute counts was highest in the $\mathrm{CMV}^{+}$population (Table 3 and Fig. 2C,D). The slight increase in per cent of senescent cytotoxic T cells as a function of age in $\mathrm{CMV}^{-}$subjects (Fig. 2C) despite declining absolute numbers of these cells (Fig. 2D) is a consequence of a significant decline in total $\mathrm{CD}^{+}$cells as a function of donor age in $\mathrm{CMV}^{-}$subjects (Fig. $2 \mathrm{E}, \mathrm{F}$ ). The difference in the mean number of $\mathrm{CD}^{+} \mathrm{T}$ cells between $\mathrm{CMV}^{+}$ and $\mathrm{CMV}^{-}$subjects (208 cells/ $\mu \mathrm{L}$ ) is essentially accounted for by the difference in mean number of senescent $\mathrm{CD} 8^{+} \mathrm{T}$ cells between these two subpopulations (200 cells / $\mu \mathrm{L}$ ) (Table 3). Although the $\% \mathrm{CD} 8^{+} \mathrm{CD} 28^{+}$cells at baseline was significantly higher in $\mathrm{CMV}^{-}$subjects $(p<0.0001)$, this was due primarily to the elevated absolute number of $\mathrm{CD} 8^{+} \mathrm{CD} 28^{-}$cells in the $\mathrm{CMV}^{+}$subset (i.e., an increased denominator for the $\mathrm{CMV}^{+}$ group). The absolute number of nonsenescent cytotoxic $\mathrm{T}$ cells $\left(\mathrm{CD}^{+} \mathrm{CD}^{-} 8^{+}\right)$was not significantly different between $\mathrm{CMV}^{+}$ and $\mathrm{CMV}^{-}$subjects (Table 3 ).

$\mathrm{CMV}^{+}$subjects had significantly fewer absolute and percent naïve cytotoxic $\mathrm{T}$ cells $\left(\mathrm{CD} 8^{+} \mathrm{CD}^{-} 5^{-}\right)$at baseline than did $\mathrm{CMV}^{-}$subjects $(p<0.0005$ and 0.07 , respectively) (Table $3)$, but in both populations there was dramatic reduction in the absolute and relative abundance of these cells as a function of subject age (Fig. $2 \mathrm{G}, \mathrm{H}$ ), consistent with previous studies. ${ }^{47,48}$ In 80 - to 90 -year-old subjects, there were $<50$ naïve $\mathrm{CD}^{+}$cells $/ \mu \mathrm{L}$.

A novel finding in the baseline dataset is an apparent effect of CMV infection on neutrophils: $\mathrm{CMV}^{-}$subjects show an increase in neutrophil number and percentage as a function of subject age compared to an essentially flat profile with age for the $\mathrm{CMV}^{+}$subjects (Fig. 2I,J). At baseline, the mean number of neutrophils in $\mathrm{CMV}^{-}$subjects was about $20 \%$ higher than that in $\mathrm{CMV}^{+}$subjects $(p=0.02$ by absolute counts, $p=0.003$ by $\%$ ) (Table 3 ). There was also highly significant increase in baseline percent $(p=0.00015)$ and absolute numbers of NK cells $(p=0.006)$ in the total population (Table 2), but there was no significant difference between $\mathrm{CMV}^{-}$and $\mathrm{CMV}^{+}$subjects.

\section{Changes from baseline}

Reduction in percent cells with short telomeres. Two independent measures of median or mean telomere length (by FlowFISH and qPCR) showed no consistent change with time on PattonProtocol-1 (data not shown). However, we also analyzed the distribution of individual telomere lengths using automated high-throughput confocal microscopy (HT $\mathrm{qFISH}^{42}$ ). Telomere signals within the nuclei of white blood cells were analyzed from 13 subjects at baseline and a followup time point between 12 or 18 months. Mean telomere length by HT qFISH correlates relatively well with median telomere length by FlowFISH (supplemental data S2) and and although some individuals showed a significant increase or decrease (Fig. 3A), overall there was no significant decline in mean telomere length by HT qFISH $(p=0.29)$. However, HT qFISH revealed a decline in the percentage of nuclei with short telomeres $(<4 \mathrm{kbp})$ in 10 of the 13 individuals $(p<0.05$ for 7 of those 10) at 12-18 months compared to baseline, while only one of the remaining 3 individuals had a significant increase in percent short telomeres (Fig. 3B). Given these data, we used a one-tailed paired $t$-test to determine the probability that the overall mean reduction across all 13 subjects was due to chance $(p=0.038)$. In separate studies in murine cells in culture and in vivo we have shown that TA$65^{\circledR}$ alone will reduce the percentage of cells with short telomeres with minimal effects on mean telomere length (M.B., manuscript in preparation).

Positive remodeling of the immune system. There were a number of striking changes from baseline in the adaptive and innate immune system of subjects on PattonProtocol-1. We saw statistically significant "age-reversal" effects in the 

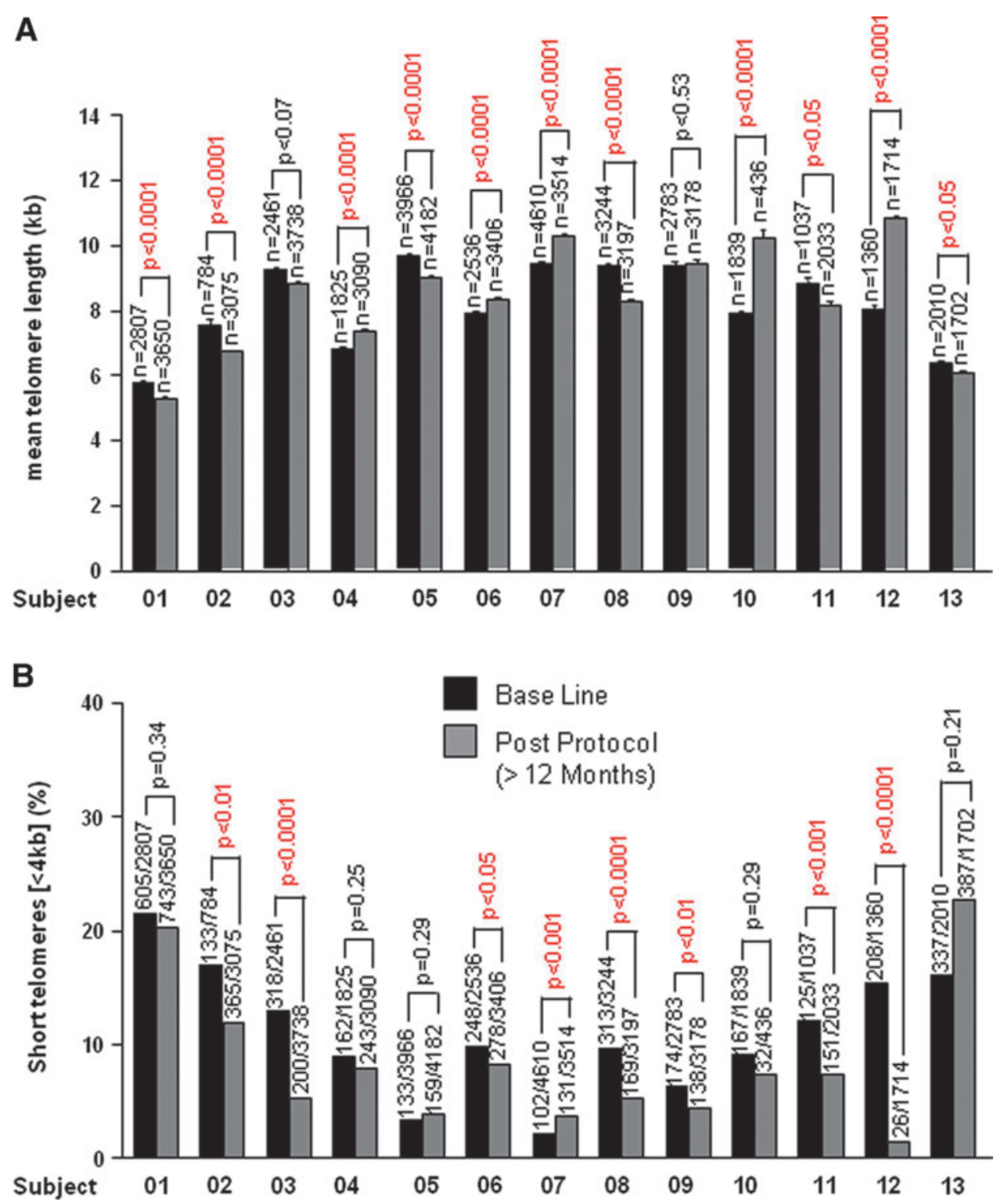

FIG. 3. Mean telomere length and percent of nuclei with short telomeres at baseline and post TAS protocol. (A) Mean telomere length values \pm standard error (SE) of the indicated individuals at base line (black bars) and post PattonProtocol-1 (grey bars) as determined by high-throughput quantitative fluorescent in situ hybridization (HT qFISH). The total number of nuclei analyzed is indicated (n) on top of each bar. Statistical significance was assessed by the Student $t$-test. (B) Percentage of nuclei with short $(<4 \mathrm{~kb})$ telomeres at base line (black bars) and post-TAS protocol (grey bars) as determined by high throughput (HT) qFISH. Numbers above bars represents the number of nuclei with short telomeres $(<4 \mathrm{~kb})$ out of the total number of nuclei analyzed. The chi-squared test was used to evaluate the statistical significance for each individual tested.

number and percent of senescent $\left(\mathrm{CD}^{+} \mathrm{CD} 28^{-}\right)$cytotoxic $\mathrm{T}$ cells, particularly after 3 months (Fig. 4A). Senescent $\mathrm{CD}^{+} \mathrm{CD} 28^{-} \mathrm{T}$ cells dropped with a linear trend from roughly $39 \%$ in the baseline population to about $36 \%$ at 12 months in the overall population $(p=0.0068$ at $12 \mathrm{M})$. Most of this effect was due to a $20 \%$ drop in the number of $\mathrm{CD}^{+} \mathrm{CD} 28^{-}$cells in the $\mathrm{CMV}^{+}$population (Fig. 4D, $p=0.0044$ at $12 \mathrm{M})$. This decrease, relative to the age-related increase of $0.57 \%$ /year and $3 \mathrm{CD}^{-} 8^{-}$cells/year in $\mathrm{CMV}^{+}$ individuals, represent an apparent age reversal of $\approx 5-20$ years in this biomarker of immune aging.

At baseline, $\mathrm{CMV}^{+}$individuals had a significantly lower number and percent of neutrophils compared to $\mathrm{CMV}^{-}$in- dividuals (Table 3). After 3 months on PattonProtocol-1, there was an overall increase in number and percent of neutrophils (Fig. 4B) which was primarily driven by the effects of the Protocol in the $\mathrm{CMV}^{+}$subjects (Fig. 4D), suggesting that as in the case with $\mathrm{CD} 28^{-}$cells, PattonProtocol-1 may reverse a potentially detrimental effect of CMV infection on neutrophils.

The percent and number of NK cells significantly decreased after about 6 months on product (Fig. 4C). A decrease was observed in both $\mathrm{CMV}^{+}$and $\mathrm{CMV}^{-}$individuals, but again the effect was more pronounced in the $\mathrm{CMV}^{+}$ population (data not shown). The changes at 12 months in the overall population (about a 15\% decline in both $\%$ and 
A

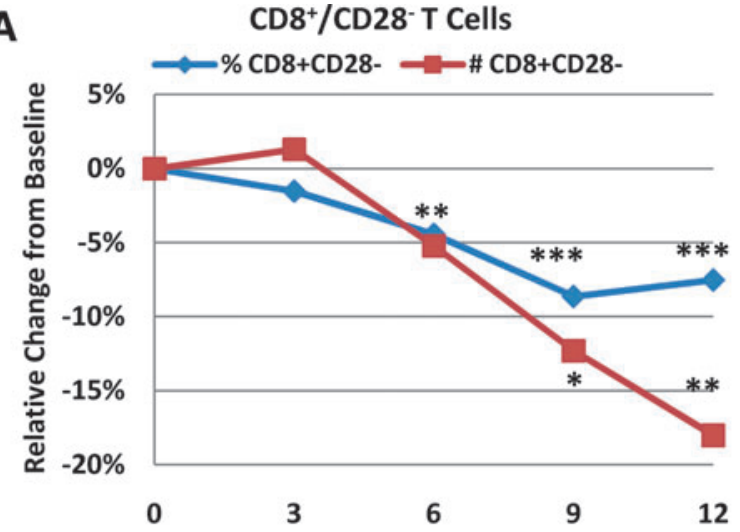

C

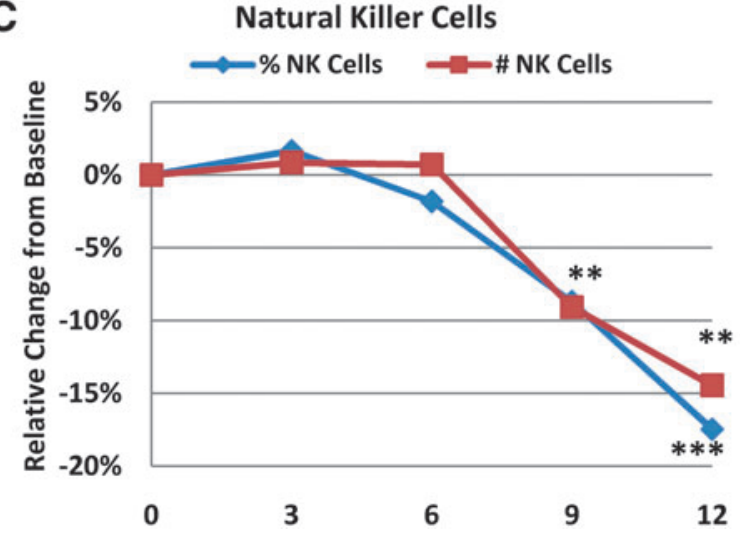

B

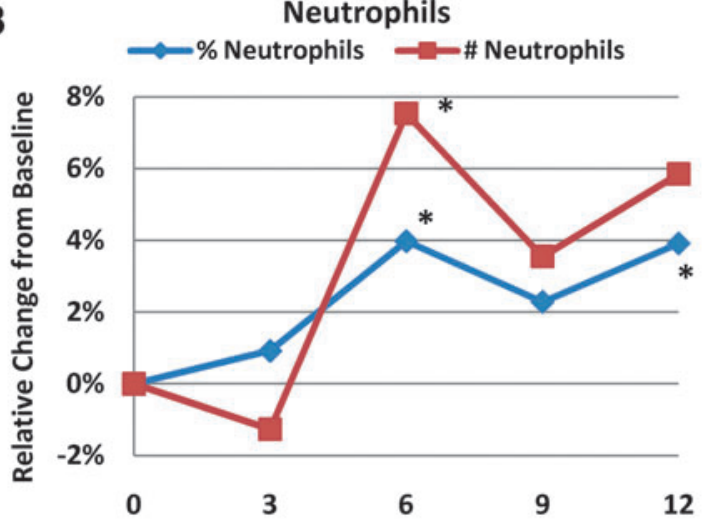

D $\quad \mathrm{CMV}+$ Immune Subset Changes

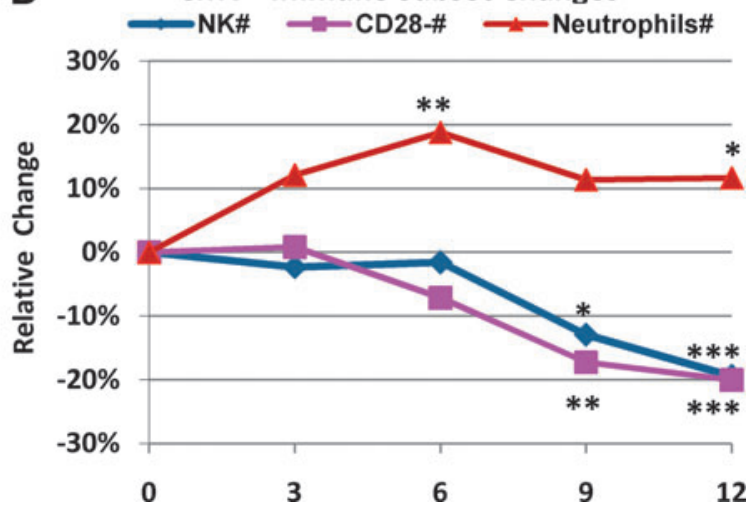

FIG. 4. Relative changes from baseline as a function of time (months) for immune subsets. The mean of the absolute change from baseline for each parameter across all subjects for which data at that time point was calculated and then expressed as a percent change from the mean value at baseline for those subjects. In A-C, data for both cytomegalovirus-positive $\left(\mathrm{CMV}^{+}\right)$ and $\mathrm{CMV}^{-}$subjects are combined. (D) Relative mean change is shown for the $\mathrm{CMV}^{+}$population subpopulation only. Asterisks next to a data point signifies $p<0.01\left(^{* * *}\right), p<0.05\left(^{* *}\right)$, and $p<0.1\left(^{*}\right)$ for a two-tailed paired (within-subject) $t$-test analysis comparing baseline to time point values.

number of NK cells) was highly significant $(p=0.0035$ and 0.0021 for number and per cent cells, respectively), and dramatic compared to the baseline increases per year in NK cells for the $\mathrm{CMV}^{+}$group $(+2.4$ cells per year and $+0.3 \%$ per year).

\section{Discussion and Conclusions}

The inability to maintain telomeres with age and chronic stress has been linked to declining health and the increased risk of disease and death from many causes, including cancer. ${ }^{16,25,49-52}$ In this study, we report that a 1-year health maintenance program consisting of a dietary supplement pack combined with a natural product-derived telomerase activator results in a decreased percentage of short leukocyte telomeres and remodeling of the relative proportions of the circulating leukocytes of $\mathrm{CMV}^{+}$subjects toward the more "youthful" profile of $\mathrm{CMV}^{-}$subjects.

One of the strengths of our study is the low CMVpositivity rate $(54 \%)$ in a relatively older population, which allows us to separate the effects of age and CMV status on immunosenescence. It also serves to mitigate one of our study's weaknesses-the lack of a control group-as the subjects were initially unaware of their CMV status and their subsequent knowledge is unlikely to have caused the segregation of many of the effects of the protocol by CMV status.

Our description of the decrease in $\mathrm{CD} 8^{+} \mathrm{CD} 28^{-} \mathrm{T}$ cells as a positive remodeling of the immune system is supported by the increased morbidity and mortality associated with what is known as the immune risk profile (IRP). This profile has been defined as a CD4/CD8 less than 1 in association with CMV seropositivity by longitudinal studies of individuals in their eighties and nineties in the OCTO/NONA Swedish cohort. ${ }^{53}$ As in our cohort, the major driving force for the decreased CD4/CD8 in $\mathrm{CMV}^{+}$subjects in this population is likely the accumulation of virus-specific $\mathrm{CD} 8^{+} \mathrm{CD} 28^{-} \mathrm{T}$ cells. These studies have reported 6-year follow-up data, and no individuals who have survived to 100 years old exhibit the IRP, even if they are $\mathrm{CMV}^{+}$. The authors conclude that successful immune aging entails being able to control CMV infection without accumulating senescent cytotoxic $\mathrm{T}$ cells. Thus, we conclude that the $20 \%$ reduction in $\mathrm{CD} 8^{+} \mathrm{CD} 28^{-} \mathrm{T}$ cells is a salutary effect, even though we have yet to see increases in the number of $\mathrm{CD}^{+} \mathrm{CD} 28^{+} \mathrm{T}$ cells. Telomere shortening associated with replicative senescence is the probable cause of loss of CD28 expression and apoptosis resistance of $\mathrm{CD}^{+}{ }^{\mathrm{T}}$ cells. ${ }^{54}$ The decrease in the percentage 
of short telomeres we found makes upregulation of telomerase by TA-65 the most likely mechanism for this salutary effect.

Age-related changes in the innate immune system have not been as well characterized as those of the adaptive immune system, although the importance of changes in the former is increasingly being recognized. ${ }^{55}$ It is generally agreed that the per-cell activity of neutrophils as measured by oxidative burst, phagocytosis, and chemotaxis decreases with age. ${ }^{56}$ There is less agreement on the effect of aging on neutrophil number which has been variously reported to be preserved, $^{57}$ decreased, $^{58}$ or increased ${ }^{53}$ with age. CMV status is not reported in the first two studies, but in the last study from the above-mentioned NONA cohort, the increase in neutrophil number is based on a comparison between 18 middle-aged (55-year-old) subjects with a 55\% $\mathrm{CMV}^{+}$prevalence rate and 120 very old subjects (92-100-year-old) with a $87 \% \mathrm{CMV}^{+}$prevalence rate. Most of the cross-sectional increase of 960 neutrophils occurs within the 92 to 100 year olds, with only a 52-cell increase between 55 and 92. There is also a significant longitudinal increase over a 6-year interval in the very old group. This suggests that there is selection for those very old subjects able to increase their circulating neutrophils in the face of deteriorating tissues, increased inflammation, and increased exposure to infectious agents. Our novel finding that by age 62 the neutrophil number is $20 \%$ higher and continues to increase with age only in $\mathrm{CMV}^{-}$ subjects can be interpreted as a compensatory increase in the face of declining per cell activity and barrier function, as well as increased antigenic load. The absence of a cross-sectional increase with age in neutrophil number in $\mathrm{CMV}^{+}$subjects suggests that this compensation is blocked in the $\mathrm{CMV}^{+}$ subjects perhaps due to inhibitory cytokine production by the senescent $\mathrm{T}$ cells. The effect of the protocol to increase neutrophil count in $\mathrm{CMV}^{+}$subjects can be interpreted as a salutary removal of this block in part through reduction in the number of senescent $\mathrm{T}$ cells.

There is a broad consensus that NK cell number increases with age to compensate for decreased per-cell activity, which results from impaired signal transduction, ${ }^{59}$ but other mechanisms such as decreased barrier function and increased antigenic/pathogenic load may also contribute to increased NK cells with age. ${ }^{60}$ The decrease in NK cell number induced by the protocol is an "age reversal," but because we did not measure NK activity we cannot say whether it is from improved barrier function or improved signal transduction. Unlike other cells of the innate immune system, NK cells proliferate after activation and experience further telomere shortening once they are released from the bone marrow. ${ }^{61}$ The decrease in the percentage of short telomeres we found could result in improved signal transduction as a mechanism for the reduction in NK cell number. Taken together, these three changes in leukocyte number induced by the protocol represent a remodeling of the immune systems of $\mathrm{CMV}^{+}$subjects to look more like those of $\mathrm{CMV}^{-}$subjects and successfully aging $\mathrm{CMV}^{+}$centenarians.

Physicians who monitored the health of the current study subjects through 1 year on the product reported no adverse events that were likely related to the protocol. However, 2 subjects who recently escalated their daily dose reported feeling "anxious" on $100 \mathrm{mg} /$ day but not when they switched back to $50 \mathrm{mg} /$ day. A placebo-controlled study will be needed to determine if this potential adverse effect is real. No new cases of cancer or cardiovascular disease were reported during the overall 260 person-years of dosing with PattonProtocol-1 through June, 2010, and this is statistically significant $(p<0.05$, cancer; $p<0.02$, CVD ) assuming baseline age-specific risks in our population were similar to those of the U.S. population.

TA- $65^{\circledR}$ activated telomerase in cultured human cells at concentrations seen in the plasma of subjects on the protocol. Paradoxically, although $\approx 40 \%$ of subjects showed an increase in mean telomere length over time, on average across all subjects there was a nonsignificant decline in mean telomere length. However, we speculate this effect is explained by cell dynamics and the fact that telomerase preferentially lengths the shortest telomeres. ${ }^{62-64}$ Rescue and selective expansion of near-senescent cells with short telomeres could lead to a reduction in the population mean telomere length despite some lengthening of telomeres in all cells. Because detrimental effects of telomere loss are primarily driven by short, dysfunctional telomeres, and loss of tissue function and disease onset in proliferative tissues have been associated with telomere lengths $<4 \mathrm{kbp},{ }^{25,65}$ we believe that our observed reduction in telomeres $<4 \mathrm{kbp}$ in subjects on PattonProtocol- 1 is a significant, positive response, and that TA- $65^{\circledR}$ contributes to the apparent benefit of the dietary supplement. In support of this, studies with TA- $65^{\circledR}$ given orally in old mice showed similar reductions in percent cells with short telomeres and positive functional effects on tissues (Blasco et al., submitted) and preliminary dose-response analyses showed an increase in salutary effects with TA- $65^{\circledR}$ doses up to 20-30 mg per day average compared to the initial 5- to 10mg per day dose (data not shown). Finally, analysis of additional biomarkers of aging in subjects on PattonProtocol-1 suggest improvements in the cardiovascular system, metabolism, and bone mineral density, which will be further studied and reported elsewhere. Independent randomized controlled studies with TA-65® alone are planned.

\section{Acknowledgments}

We thank Drs. Tom Okarma, Spencer Brown, and Rita Effros for critical review of the manuscript, and Noel Patton for patience, encouragement, and financial support of the studies. We also thank the early telomerase activation team at Geron Corporation for generating data in human keratinocytes, Marissa Chunisingh for acting as a key interface between clients and TA Sciences staff, and Drs. Nathan Wong and Sherman Xi for critical feedback and help with statistical analyses.

\section{Author Disclosure Statement}

Calvin Harley is one of the inventors of TA-65. He consults for TA Sciences and is personally taking TA-65 and is one of the subjects studied to generate data for this article. He owns stock and stock options in Geron Corporation, a company that is developing telomerase activators for therapeutic purposes and the company that licensed TA-65 to TA Sciences. He is cofounder, President, and CEO, and holds stock in Telome Health, Inc., a diagnostics company that will provide telomere- and telomerase-related assay services to the healthcare industry. Joseph Raffaele consults for TA Sciences; he is CEO of PhysioAge Systems, LLC, a company that provides bio- 
markers of aging analysis, including telomere lengths, to medical practices, and he is co-founder of PhysioAge Medical Group which offers TA-65 through the Patton Protocol. William H. Andrews owns stock or membership options in Geron Corporation and Sierra Sciences; he consults for TA Science, is a client of TA Sciences who is taking TA-65, and is one of the subjects studied to generate data for this manuscript. He is the founder, President, and CEO of Sierra Sciences, a company that develops therapeutics for inducing telomerase expression and has provided financial support for some of the studies described in this manuscript. Weimin Liu is an employee of TA Sciences. Elsa Vera and Maria Blasco have no competing financial interests.

\section{References}

1. Marik PE, Varon J. Omega-3 dietary supplements and the risk of cardiovascular events: A systematic review. Clin Cardiol 2009;32:365-372.

2. Khandanpour N, Armon MP, Jennings B, Finglas PM, Willis G, Clark A, Meyer FJ. Randomized clinical trial of folate supplementation in patients with peripheral arterial disease. Br J Surg 2009;96:990-998.

3. Bemis DL, Katz AE, Buttyan R. Clinical trials of natural products as chemopreventive agents for prostate cancer. Expert Opin Investig Drugs 2006;15:1191-1200.

4. Iannitti T, Palmieri B. Antioxidant therapy effectiveness: an up to date. Eur Rev Med Pharmacol Sci 2009;13:245-278.

5. Judd SE, Tangpricha V. Vitamin D deficiency and risk for cardiovascular disease. Am J Med Sci 2009;338:40-44.

6. Nigwekar SU, Kandula P. N-acetylcysteine in cardiovascular-surgery-associated renal failure: A meta-analysis. Ann Thorac Surg 2009;87:139-147.

7. Blackburn EH, Greider CW, Szostak JW. Telomeres and telomerase: the path from maize, Tetrahymena and yeast to human cancer and aging. Nat Med 2006;12:1133-1138.

8. Harley CB. Telomerase therapeutics for degenerative diseases. Curr Mol Med 2005;5:205-211.

9. Ayouaz A, Raynaud C, Heride C, Revaud D, Sabatier L. Telomeres: Hallmarks of radiosensitivity. Biochimie 2008;90: 60-72.

10. Wright DL, Jones E, Mayer J, Oehninger S, Gibbons W, Lanzendorf SE. Characterization of telomerase activity in the human oocyte and preimplantation embryo. Mol Hum Reprod 2001;7:947-955.

11. Ulaner GA, Giudice LC. Developmental regulation of telomerase activity in human fetal tissues during gestation. Mol Hum Reprod 1997;3:769-773.

12. Harley CB. Telomerase is not an oncogene. Oncogene 2002;21:494-502.

13. Flores I, Benetti R, Blasco MA. Telomerase regulation and stem cell behaviour. Curr Opin Cell Biol 2006;18:254-260.

14. Effros RB. Telomerase induction in T cells: A cure for aging and disease? Gerontol 2007;42:416-420.

15. Effros RB. Genetic alterations in the ageing immune system: Impact on infection and cancer. Mech Ageing Dev 2003; 124:71-77.

16. Epel ES. Psychological and metabolic stress: a recipe for accelerated cellular aging? Hormones (Athens) 2009;8:7-22.

17. von Zglinicki T. Oxidative stress shortens telomeres. Trends Biochem Sci 2002;27:339-344.

18. Epel ES, Blackburn EH, Lin J, Dhabhar FS, Adler NE, Morrow JD, Cawthon RM. Accelerated telomere shortening in response to life stress. Proc Natl Acad Sci USA 2004;101: 17312-17315.

19. Harley $C B$, Futcher $A B$, Greider CW. Telomeres shorten during ageing of human fibroblasts. Nature 1990;345:458-460.

20. Hastie ND, Dempster M, Dunlop MG, Thompson AM, Green DK, Allshire RC. Telomere reduction in human colorectal carcinoma and with ageing. Nature 1990;346:866-868.

21. Garcia CK, Wright WE, Shay JW. Human diseases of telomerase dysfunction: insights into Tissue aging. Nucleic Acids Res 2007;35:7406-7416.

22. Armanios MY, Chenn JJ, Cogan JD, Alder JK, Ingersoll RG, Markin C, Lawson WE, Xie M, Vulto I, Phillips JAr, Lansdorp PM, Greider CW, Loyd JE. Telomerase mutations in families with idiopathic pulmonary fibrosis. N Engl J Med 2007;356:1370-1372.

23. Sebastian C, Herrero C, Serra M, Lloberas J, Blasco MA, Celada A. Telomere shortening and oxidative stress in aged macrophages results in impaired STAT5a phosphorylation. J Immunol 2009;183:2356-2364.

24. Calado RT. Telomeres and marrow failure. Hematology Am Soc Hematol Educ Program 2009:338-343.

25. Calado RT, Young NS. Telomere diseases. N Engl J Med 2009;361:2353-2365.

26. Rajaraman S, Choi J, Cheung P, Beaudry V, Moore H, Artandi SE. Telomere uncapping in progenitor cells with critical telomere shortening is coupled to S-phase progression in vivo. Proc Natl Acad Sci USA 2007;104:1774717752.

27. Cawthon RM, Smith KR, O'Brien E, Sivatchenko A, Kerber RA. Association between telomere length in blood and mortality in people aged 60 years or older. Lancet 2003;361:359-395.

28. Savage SA, Alter BP. The role of telomere biology in bone marrow failure and other disorders. Mech Ageing Dev 2008;129:35-47.

29. Aviv A, Valdes A, Gardner JP, Swaminathan R, Kimura M, Spector TD. Menopause modifies the association of leukocyte telomere length with insulin resistance and inflammation. J Clin Endocrinol Metab 2006;91:635-640.

30. Lukens JN, Van Deerlin V, Clark CM, Xie SX, Johnson FB. Comparisons of telomere lengths in peripheral blood and cerebellum in Alzheimer's disease. Alzheimers Dement 2009;5:463-469.

31. Weyand CM, Fujii H, Shao L, Goronzy JJ. Rejuvenating the immune system in rheumatoid arthritis. Nat Rev Rheumatol 2009;5:583-588.

32. Spyridopoulos I, Hoffmann J, Aicher A, Brummendorf TH, Doerr HW, Zeiher AM, Dimmeler S. Accelerated telomere shortening in leukocyte subpopulations of patients with coronary heart disease: role of cytomegalovirus seropositivity. Circulation 2009;120:1364-1372.

33. Effros RB. Telomerase induction in T cells: A cure for aging and disease? Exp Gerontol 2007;42:416-420.

34. Lichterfeld M, Mou D, Cung TD, Williams KL, Waring MT, Huang J, Pereyra F, Trocha A, Freeman GJ, Rosenberg ES, Walker BD, Yu XG. Telomerase activity of HIV-1-specific CD8+ T cells: constitutive up-regulation in controllers and selective increase by blockade of PD ligand 1 in progressors. Blood 2008;112:3679-3687.

35. Dagarag M, Evazyan T, Rao N, Effros RB. Genetic manipulation of telomerase in HIV-specific CD8 T cells: enhanced anti-viral functions accompany the increased proliferative potential and telomere stabilization. J Immunol 2004;173: 6303-6311. 
36. Fauce SR, Jamieson BD, Chin AC, Mitsuyasu RT, Parish ST, $\mathrm{Ng}$ HL, Kitchen CM, Yang OO, Harley CB, Effros RB. Telomerase-based pharmacologic enhancement of antiviral function of human CD8+ $\mathrm{T}$ lymphocytes. J Immunol 2008;181:7400-7406.

37. Pawelec G, Derhovanessian E, Larbi A, Strindhall J, Wikby A. Cytomegalovirus and human immunosenescence. Rev Med Virol 2009;19:47-56.

38. Dowd JB, Zajacova A, Aiello A. Early origins of health disparities: burden of infection, health, and socioeconomic status in U.S. children. Soc Sci Med 2009;68:699-707.

39. Kim NW, Wu F. Advances in quantification and characterization of telomerase activity by the telomeric repeat amplification protocol (TRAP). Nucleic Acids Res 1997;25:2595-2597.

40. Baerlocher GM, Vulto I, de Jong G, Lansdorp PM. Flow cytometry and FISH to measure the average length of telomeres (flow FISH). Nat Protoc 2006;1:2365-2376.

41. Cawthon RM. Telomere length measurement by a novel monochrome multiplex quantitative PCR method. Nucleic Acids Res 2009;37:e21.

42. Canela A, Vera E, Klatt P, Blasco MA. High-throughput telomere length quantification by FISH and its application to human population studies. Proc Natl Acad Sci USA 2007;104:5300-5305.

43. Vaziri H, Dragowska W, Allsopp RC, Thomas TE, Harley CB, Lansdorp PM. Evidence for a mitotic clock in human hematopoietic stem cells: Loss of telomeric DNA with age. Proc Natl Acad Sci USA 1994;91:9857-9860.

44. Rufer N, Brummendorf TH, Kolvraa S, Bischoff C, Christensen K, Wadsworth L, Schulzer M, Lansdorp PM. Telomere fluorescence measurements in granulocytes and $\mathrm{T}$ lymphocyte subsets point to a high turnover of hematopoietic stem cells and memory T cells in early childhood. J Exp Med 1999;190:157-167.

45. Frenck RW, Blackburn EH, Shannon KM. The rate of telomere sequence loss in human leukocytes varies with age. Proc Natl Acad Sci USA 1998;95:5607-5610.

46. Chidrawar S, Khan N, Wei W, McLarnon A, Smith N, Nayak L, Moss P. Cytomegalovirus-seropositivity has a profound influence on the magnitude of major lymphoid subsets within healthy individuals. Clin Exp Immunol 2009;155:423-432.

47. Hadrup SR, Strindhall J, Kollgaard T, Seremet T, Johansson B, Pawelec G, thor Straten P, Wikby A. Longitudinal studies of clonally expanded CD8 $\mathrm{T}$ cells reveal a repertoire shrinkage predicting mortality and an increased number of dysfunctional cytomegalovirus-specific $\mathrm{T}$ cells in the very elderly. J Immunol 2006;176:2645-2653.

48. Effros RB, Pawelec G. Replicative senescence of T cells: Does the hayflick limit lead to immune exhaustion? Immunol Today 1997;18:450-454.

49. Cawthon RM. Telomere measurement by quantitative PCR. Nucleic Acids Res 2002;30.

50. Farzaneh-Far R, Lin J, Epel E, Lapham K, Blackburn E, Whooley MA. Telomere length trajectory and its determinants in persons with coronary artery disease: longitudinal findings from the heart and soul study. PLoS One 2010;5:e8612.

51. Brouilette SW, Whittaker A, Stevens SE, van der Harst P, Goodall AH, Samani NJ. Telomere length is shorter in healthy offspring of subjects with coronary artery disease: Support for the telomere hypothesis. Heart 2008;94:422-425.

52. van der Harst P, van der Steege G, de Boer RA, Voors AA, Hall AS, Mulder MJ, van Gilst WH, van Veldhuisen DJ.
Telomere length of circulating leukocytes is decreased in patients with chronic heart failure. J Am Coll Cardiol 2007;49:1459-1464.

53. Strindhall J, Nilsson BO, Lofgren S, Ernerudh J, Pawelec G, Johansson B, Wikby A. No Immune Risk Profile among individuals who reach 100 years of age: Findings from the Swedish NONA immune longitudinal study. Exp Gerontol 2007;42:753-761.

54. Effros RB, Dagarag M, Spaulding C, Man J. The role of $\mathrm{CD} 8+\mathrm{T}$-cell replicative senescence in human aging. Immunol Rev 2005;205:147-157.

55. Gomez CR, Nomellini V, Faunce DE, Kovacs EJ. Innate immunity and aging. Exp Gerontol 2008;43:718-728.

56. Wenisch C, Patruta S, Daxbock F, Krause R, Horl W. Effect of age on human neutrophil function. J Leukoc Biol 2000;67:40-45.

57. Chatta GS, Andrews RG, Rodger E, Schrag M, Hammond WP, Dale DC. Hematopoietic progenitors and aging: alterations in granulocytic precursors and responsiveness to recombinant human G-CSF, GM-CSF, and IL-3. J Gerontol 1993;48:M207-M212.

58. De Martinis M, Modesti M, Ginaldi L. Phenotypic and functional changes of circulating monocytes and polymorphonuclear leucocytes from elderly persons. Immunol Cell Biol 2004;82:415-420.

59. Panda A, Arjona A, Sapey E, Bai F, Fikrig E, Montgomery RR, Lord JM, Shaw AC. Human innate immunosenescence: causes and consequences for immunity in old age. Trends Immunol 2009;30:325-333.

60. Solana R, Alonso MC, Pena J. Natural killer cells in healthy aging. Exp Gerontol 1999;34:435-443.

61. Mariani E, Meneghetti A, Formentini I, Neri S, Cattini L, Ravaglia G, Forti P, Facchini A. Different rates of telomere shortening and telomerase activity reduction in CD8 T and CD16 NK lymphocytes with ageing. Exp Gerontol 2003;38: 653-659.

62. Hemann M, Strong M, Hao L, Greider C. The shortest telomere, not average telomere length, is critical for cell viability and chromosome stability. Cell 2001;107:67-77.

63. Samper E, Flores J, Blasco M. Restoration of telomerase activity rescues chromosomal instability and premature aging in Terc mice with short telomeres. EMBO reports 2001;2:800-807.

64. Teixeira MT, Arneric M, Sperisen P, Lingner J. Telomere length homeostasis is achieved via a switch between telomerase- extendible and -nonextendible states. Cell 2004;117: 323-335.

65. Alter BP, Baerlocher GM, Savage SA, Chanock SJ, Weksler BB, Willner JP, Peters JA, Giri N, Lansdorp PM. Very short telomere length by flow fluorescence in situ hybridization identifies patients with dyskeratosis congenita. Blood 2007;110:1439-1447.

Address correspondence to: Calvin B. Harley Telome Health, Inc. 1455 Adams Drive Menlo Park, CA 94025

E-mail: charley@telomehealth.com

Received: June 25, 2010 Accepted: August 9, 2010 